\title{
An Investigation of Factors Causing ESL Learning Anxiety in Classroom: A Case Study of ESL Learners at Shah Abdul Latif University Khairpur
}

\author{
Farah Naz Abbasi \\ Shaheed Benazir Bhutto University Shaheed Benazirabad, Sindh, Pakistan \\ Siraj Ahmed Channa \\ Shaheed Benazir Bhutto University Shaheed Benazirabad, Sindh, Pakistan
}

Shehla Anwar Kurd

University of Sindh Jamshoro

Farheen Shaikh

University of Sindh Jamshoro

\begin{abstract}
Received: July 23, 2020 Accepted: September 2, 2020 Published: September 6, 2020
doi:10.5296/elr.v6i2.17650 URL: https://doi.org/10.5296/elr.v6i2.17650
\end{abstract}

\begin{abstract}
English language plays crucial role as an official language of Pakistan and it is applied normally as a medium of instructions crossway over instructional institutions and business organizations. Since anxiety hinders the studying and learning techniques, in this way it's been widely inquired approximately the world and indicates to be underneath seemed into Pakistani context. As a result the important aim of this research is to investigating factors causing language anxiety in learning to speak English in classroom among undergraduate students of Shah Abdul Latif University Khairpur, Sindh, Pakistan. This Study followed a case study with mixed method approach using both quantitative and qualitative tactics. The population of this research study was 214 learners of English from Faculty of social sciences, Departments of Economics, International Relations and Media Studies. In this research study sampling size of 150 students was taken randomly who participated. Questionnaire used "to
\end{abstract}


know students' level of anxiety was adopted from FLCAS scale, developed by Horwitz et al (1986)". Qualitative data was also obtained by conducting semi-structured interviews from 15 students randomly from three departments, 5 from each, and classroom observation was also carried out for three weeks. The results showed that anxiety of English classes is high rated Mean=31.98, Secondly fear of negative evaluation Mean=30.62, thirdly communicative apprehension Mean=25.01 and fourthly test anxiety Mean=13.89. It indicated that students have problem of anxiety. The statistics was analyzed in element eventually each quantitative and qualitative findings have been mixed to attain the end result of the study. The Findings of study mostly shown anxiety factors in classroom and are prominent such as fear of teacher, other student's fear of being mocked, fear of making mistakes, lack of confidence, peer pressure, anxious personality, unsure about their abilities, fear of negative evaluation, worry of failing in examination tests, low proficiency, lack of vocabulary. Therefore results are significant that students have problem of anxiety while learning to speak English in classroom.

Keywords: Foreign language classroom anxiety, Anxiety factors, Research on anxiety

\section{Introduction}

English language is spoken broadly all over the world, it is referred as "world language" and also called lingua franca of present age and therefore, and it occupies a pivotal role in the world comparatively more than any other of the 6000 languages which are spoken in the world. Though the statement is based on general realization the significance of English language is expanding all around step by step. English is the world's leading international language. It works as a second foreign language in numerous nations of the world. English has a broader scope as a global language and it is also used for world business, e-commerce, in science and information technology as well as used particularly as an official language in Pakistan. It has an important position on the linguistic map of Pakistan. Anxiety has been found among different groups of people in numerous contexts as correlated with English learning achievement. It is observed that in foreign language classroom some students face anxiety that create hesitate and pounding. Anxiety has been considered among other factors as a greater factor that affect in second language acquisition. Foreign language learning anxiety affect directly on students' personality, emotions and experiences. Second language learning and foreign language learning both terms are used frequent and alternatively. It is determined that during foreign language classroom some classmate students face anxiety that create hesitate and pounding. Anxiety has been considered amongst other elements as a more component that affect in second language acquisition. Classroom teachers over and over again hear, as students proclaim that what teacher says and what they have to say, but when asked them to participate in class discussion in target language they freeze.

\subsection{Research Questions}

This study paper aims to answer the questions as listed below:

- What are the factors which create language anxiety in speaking to the learners of ESL at undergraduate level at Shah Abdul Latif University Khairpur?

- What is the level of ESL learning anxiety in speaking faced by the undergraduate students at Shah Abdul Latif University Khairpur? 


\section{Literature Review}

Rahman (2002) says that however English language is the official language of Pakistan, the local languages are in incredible assortments in country indicating immense complex in the linguistic viewpoint. Six noteworthy nearby dialects like Urdu (national dialect), Punjabi, Sindhi, Siraiki, Pashto, Balochi as (territorial dialects), and in excess of sixty languages are spoken in Pakistan. English isn't the first language and mastering English as a second language has been difficult and difficult areas for Pakistani inexperienced persons in which they're unmistakable to English just in a language magnificence In ESL/EFL context learners of speaking English have constantly been in a serious problem. The students might be fine at other skills (reading, writing and listening) but poor at speaking skill (Nazir, Bashir \& Raja, 2014, p. 216). Tanveer (2007) finds in second language classroom speaking could be the most anxiety provoking. Tien (2018) finds connection between English speaking anxiety and factors variables which influence among Taiwanese university English and non-English majors. In this study mixed method approach was utilized for information assortment. The aftereffects of the examination indicated female students experience increasingly English speaking anxiety as correlation with male learners. Furthermore, non-English majors have more English speaking anxiety than English majors. Young (1992) states, speaking skill can be very anxiety provoking as comparing to other four skills. Mostly learners learning state for English as a foreign language is full of fear, nervousness. Maclntyre and Gardner (1991a) define apprehension feelings can produce various troubles in the acquiring, production and retention of the language, and that eventually affects in learning, and low score, as equal to their peaceful and patient peers. Since the 1970s researches have been raising in the affective variables of foreign language learning and teaching. Many language educators perceived that it is not only an abstract exercise to memorize vocabulary and apply grammatical rules, but learners also face difficulties in language acquisition as stress and ambiguities in communication due to unfamiliar culture. Horwitz (1986) finds learners who considered themselves as wisely intelligent and skillful individuals as a socially generally doubtful uneasy and nervous while communicating second/foreign language due to unsure and unfamiliar linguistic and socio cultural standards. Foreign language learning for many learners can be sometimes most painful experience as well.

\section{Research Methodology}

Duff (in press cited in Dornyei, p.155) reports that case studies have been ever more used in mixed methods studies. This study is based on mixed methods; both qualitative as well as quantitative were used in the study. This investigation was carried with a mixed methods approach, qualitative and quantitative techniques and tools utilized were questionnaires, semi-structured Interviews and observation.

Questionnaire utilized as a part of this investigation was the Foreign Language Classroom Anxiety Scale (FLCAS), composed by Horwitz et al. (1986) to evaluate learners nervousness in English class based on of 33 items (5-point Likert scale). Semi structured interviews from 15 students 5 from each department and classroom observation over three week in above classes. Focal point of observation was on every individual learner's level of participation in classroom activities, verbal correspondence with the instructor and with peers, verbal and non-verbal articulation and conduct indicating nervousness, avoidance and 


\section{Macrothink}

troubles in taking an interest in classroom activities assuming if any. "SPSS" statistical package for social sciences applied for analysis and interpretation of quantitative data. Interviews were recorded and transcribed on paper. According to Braun \& Clarke (2006) "thematic analysis is a method used for "recognizing, breaking down, and revealing examples (themes) inside the data" (2006, p.79).

This investigation based on 33 items which is proposed to evaluate four areas and components classified items and distinguished as under; i.e. Communication Apprehension, 1,9,14,18,24,27,29,32 Test Anxiety, 2,8,10,19,21, Fear of Negative Evaluation, $3,7,13,15,23,25,31,33$ and Anxiety in English classes, 4,5,6,11,12,16,17,22,26,28,30. The components classified and distinguished are as under;

\section{Data Analysis}

\subsection{Quantitative Data Analysis}

Table 1. Reliability Statistics

\begin{tabular}{|llll|}
\hline S.NO & Subscales & Cronbach Alpha Values & No's \\
\hline $\mathbf{1}$ & Communicative Apprehension & .985 & 8 \\
$\mathbf{2}$ & Test Anxiety & .967 & 5 \\
$\mathbf{3}$ & Fear of Negative Evaluation & .989 & 9 \\
$\mathbf{4}$ & Anxiety of English Classes & .988 & 11 \\
\hline
\end{tabular}

The results of SPSS are quite satisfactory, which gave satisfaction to use questionnaire tool for the main study in the context of SALU Khairpur.

Table 2. Statistics for communicative apprehension

\begin{tabular}{|l|l|l|l|}
\hline Items & Mean & $\begin{array}{l}\text { STD } \\
\text { Deviation }\end{array}$ & N \\
\hline $\begin{array}{l}\text { I certainly not feel very certain of myself when I am talking in my } \\
\text { foreign language class }\end{array}$ & 3.67 & 1.091 & 150 \\
\hline $\begin{array}{l}\text { I begin to frighten when I need to talk in language class without } \\
\text { preparation }\end{array}$ & 3.33 & 1.191 & 150 \\
\hline $\begin{array}{l}\text { I wouldn't be anxious talking the foreign language with local } \\
\text { speakers }\end{array}$ & 2.52 & 1.168 & 150 \\
\hline I feel sure when I talk in foreign language class & 2.31 & 1.129 & 150 \\
\hline $\begin{array}{l}\text { I feel exceptionally nervous about talking the foreign language } \\
\text { before different learners }\end{array}$ & 3.73 & 1.263 & 150 \\
\hline $\begin{array}{l}\text { I become apprehensive and confounded when I am talking in my } \\
\text { language class }\end{array}$ & 3.04 & 1.187 & 150 \\
\hline I become apprehensive when I don't apprehend each term the & 3.65 & 1.296 & 150 \\
\hline
\end{tabular}




\begin{tabular}{|l|l|l|l|}
\hline language instructor say & & & \\
\hline $\begin{array}{l}\text { I would presumably presume well about local foreign language } \\
\text { speakers. }\end{array}$ & 2.77 & 1.083 & 150 \\
\hline
\end{tabular}

This table shows learners ' level of language anxiety in communicative apprehension. Students' reactions on various things were recorded and analyzed using SPSS 21. Learners supported a statement demonstrating communication apprehension like in statement 24 results shows as, Mean 3.73, Standard Deviation SD 1.263 in which 33.3\% agree and $4.7 \%$ disagree. This indicates that they are not interested in learning to speak foreign language in front of other students because they feel nervous and shy. The statement 1 shows result as Mean 3.67, SD 1.091 in which $41 \%$ agreed and $14 \%$ disagree. It indicates that they are unsure about themselves during speaking in English classroom. In statement 29 result shows as, Mean 3.65, SD 1.296 in which $34 \%$ agreed and 10\% disagree. It indicates majority of students are nervous as they don't apprehend each term of the teacher.

Table 3. Statistics for Test Anxiety

\begin{tabular}{|l|l|l|l|}
\hline Items & Mean & $\begin{array}{l}\text { STD } \\
\text { deviation }\end{array}$ & N \\
\hline I don't upset over committing errors in language class. & 2.80 & 1.099 & 150 \\
\hline I am more often at relieved in my language class throughout tests. & 2.47 & 1.427 & 150 \\
\hline I stress over the outcomes of failing my foreign language class & 3.13 & 1.312 & 150 \\
\hline $\begin{array}{l}\text { The more I contemplate for a language test, the more puzzled I } \\
\text { become }\end{array}$ & 3.41 & 1.631 & 150 \\
\hline $\begin{array}{l}\text { I continue believing that other learners are good at language than I } \\
\text { am. }\end{array}$ & 2.09 & 1.068 & 150 \\
\hline
\end{tabular}

This table shows students' level of test anxiety in foreign language classroom. Students endorsed a statement indicating test anxiety like in statement 19 result shows as, Mean 3.41, SD 1.631 in which $40 \%$ strong agree and $25 \%$ strong disagree. That indicates they have fear while mistakes are being corrected by the teacher in statement 10 results shows as, Mean 3.13, std. deviation 1.312 in which $25 \%$ agree and $22 \%$ disagree. It means they are afraid of failing in test. In statement 2 result shows as, Mean 2.80, SD Deviation 1.099 in which $28 \%$ agree and $37 \%$ disagree. It indicates students disapproved the statement which means they were nervous and worried to make mistake in language class. 
Table 4. Statistics for fear of negative evaluation

\begin{tabular}{|l|l|l|l|}
\hline Items & Mean & $\begin{array}{l}\text { STD } \\
\text { Deviation }\end{array}$ & N \\
\hline I shiver when I realize that I will be called in language class. & 3.73 & 1.262 & 150 \\
\hline $\begin{array}{l}\text { I continue believing that other learners are good at language } \\
\text { than I am. }\end{array}$ & 3.48 & 1.122 & 150 \\
\hline It humiliates me to volunteer answers in my language class. & 3.55 & 1.207 & 150 \\
\hline $\begin{array}{l}\text { I become annoyed after I do not realize what the instructor is } \\
\text { fixing. }\end{array}$ & 3.23 & 1.108 & 150 \\
\hline $\begin{array}{l}\text { I'm able to sense my heart beating once I could be approached } \\
\text { in language class. }\end{array}$ & 3.10 & 1.225 & 150 \\
\hline $\begin{array}{l}\text { I commonly sense that other college students talk the overseas } \\
\text { language better than I do Language. }\end{array}$ & 3.47 & 1.060 & 150 \\
\hline $\begin{array}{l}\text { Language class move so rapidly I stress over getting left } \\
\text { behind. }\end{array}$ & 3.34 & 1.532 & 150 \\
\hline $\begin{array}{l}\text { I am worried about the opposite learners will snicker at me } \\
\text { after I talk in the foreign language }\end{array}$ & 3.45 & 1.557 & 150 \\
\hline $\begin{array}{l}\text { I am getting fearful when the language instructor makes } \\
\text { inquiries which i have not arranged in progress }\end{array}$ & 3.27 & 1.157 & 150 \\
\hline
\end{tabular}

This table shows students' level of foreign language anxiety in negative evaluation. Learners endorsed a statement indicating fear of negative evaluation in statement 3 result shows as, Mean, 3.73, SD deviation 1.262 in which $36 \%$ strongly agreed and $8 \%$ strongly disagree. It indicates learners are uneasy and fearful while they are called in language class. In statement 13 results shows as, Mean 3.55, SD ddeviation 1.207 in which $30 \%$ strongly agree and $18 \%$ strongly disagree. It indicated that students feel shy to answer voluntarily in language class. In statement 7 result shows as, Mean 3.48, Std. deviation 1.122 in which $37 \%$ agreed and $12 \%$ disagree. It indicates that they are lacking in self-confidence.

Table 5. Statistics for Anxiety of English classes

\begin{tabular}{|l|l|l|l|}
\hline Items & Mean & $\begin{array}{l}\text { STD } \\
\text { Deviation }\end{array}$ & N \\
\hline $\begin{array}{l}\text { It worries me while I don't comprehend what the instructor is talking in } \\
\text { the foreign language. }\end{array}$ & 3.17 & 1.208 & 150 \\
\hline It would not trouble me to attend all more foreign language classes. & 3.92 & 1.020 & 150 \\
\hline $\begin{array}{l}\text { During language class, I find contemplating things that have nothing to } \\
\text { do with the course. }\end{array}$ & 2.76 & 1.021 & 150 \\
\hline
\end{tabular}




\begin{tabular}{|l|l|l|l|}
\hline $\begin{array}{l}\text { I don't comprehend why a few people get so steamed at foreign } \\
\text { language classes. }\end{array}$ & 2.12 & .882 & 150 \\
\hline In Language class, I can get so anxious I overlook things I know. & 3.30 & 1.191 & 150 \\
\hline $\begin{array}{l}\text { Regardless of whether I prepared well for language class, I feel worry } \\
\text { about it. }\end{array}$ & 2.57 & 1.212 & 150 \\
\hline I frequently feel similar as not going to my language class. & 2.05 & 1.098 & 150 \\
\hline $\begin{array}{l}\text { I don't feel strain to get ready for language class. } \\
\text { different classes. }\end{array}$ & 3.06 & 1.166 & 150 \\
\hline $\begin{array}{l}\text { When I'm along the way to language class, I feel beyond any doubt } \\
\text { and stress-free. }\end{array}$ & 2.67 & 1.021 & 150 \\
\hline $\begin{array}{l}\text { I feel overpowered by the numerous of guidelines need to figure out } \\
\text { how to talk a FL. }\end{array}$ & 3.60 & 1.405 & 150 \\
\hline
\end{tabular}

This table shows level of students' in foreign language anxiety. Students endorsed a statement 5 result shows as, Mean 3.92, SD 1.020 in which 37\% agree and 6\% disagree. It indicates that they are not worried and interested to take classes and want to learn English language. In statement 30 result shows as, Mean 3.60, SD. deviation 1.405 in which 36\% strongly agreed and $14 \%$ strongly disagree. It showed that Students have problem with number of rules to speak to learn foreign language. In statement 12 result shows as, Mean 3.30, Std. deviation 1.191 in which $40 \%$ agreed and $16 \%$ disagreed. It indicates that they feel nervous and uneasy as they forget things in class which they know before.

\subsection{Interview Data}

The interviews were carried out to find out the main factors which effect on language anxiety among learners of English at SALU Khairpur. The time for each participant was given half an hour face to face. For analysis of interviews thematic analysis was used to put together the theoretical positions of Braun and Clarke (2006). These findings revealed that respondents have communicative apprehension. Some students worried because of lack of vocabulary, pronunciation, worried to follow many grammar rules some students said that they are good at other skills like writing and listening but not in speaking. Students said there is no facility of language laboratories. Through analysis data findings revealed that respondents have a fear of getting less score in test, fear of failing in test, feeling stressful before test and students unwilling to participate. The result discovered that respondents have fear of negative evaluation of teachers, even they want to participate but anxiety negatively affected their abilities of communication, nervous while speaking they forget what to say. One of respondent said he feels very anxious from cross questioning and voluntarily asking questions by the teacher. The majority of learners pointed out that in class in front of other students it's very hard to learn because they laugh at them. Respondents have greatly peer pressure. Some students showed that they can't describe their feelings because sometimes they are worried, frustrated and unhappy. 


\section{Discussion}

At the beginning students are energetic but due to some factors they become stressful resulting anxiety. It's not pre- existing in most of the cases. There are several reasons behind anxiety caused in a classroom. Moreover, as analyzing the results from quantitative and qualitative data to answer this question is that anxiety plays a vital function in the foreign language class which can create obstacles which distract learners and hinder them in comprehending what's taught in the classroom. Many students felt shy while reading newspaper in class in front of teacher and other classmates because of fear of making mistakes. Some students' voice was very low, they mispronounced words; when teacher corrected they stopped, felt confused and some students even refused to take part in different activities as they had high level of frustration.

\section{Conclusion}

It has been concluded that the foreign language classroom anxiety differs for different students based on their expertise in that language. The results showed that anxiety of English classes is high rated Mean=31.98, Secondly fear of negative evaluation Mean=30.62, thirdly communicative apprehension Mean=25.01 and fourthly test anxiety Mean=13.89. It also indicated that students have problem of anxiety If the student is good enough he/she will report lesser anxiety while some anxiety factors in classroom are prominent such as fear of teacher, other student's fear of being mocked, fear of making mistakes, lack of confidence, peer pressure, anxious personality, unsure about their abilities, fear of negative evaluation, fear of failing in tests, low proficiency, lack of vocabulary. It is an admitted fact that it is the main responsibility of the institute and teacher to create healthy atmosphere in the language classroom so as to minimize any level of anxiety which learners are facing while learning to speak L2. To get rid of fear of negative evaluation, fear to communicate, test anxiety, it is most essential to do more classroom activities in a very co-operative manner through implementing group discussion, pair work, conversation and more communication with each other in a stress free and friendly environment, which will decrease their anxiety level and increase students motivation to learn and naturally this will enhance students self-confidence.

\section{References}

Ahmed, N., Pathan, H, Z., \& Khan, S, F.(2017). Exploring the causes of English anxiety among postgraduate students of university of Baluchistan, Pakistan. International Journal of English Linguistics, 07(02), 99-105. https://doi.org/10.5539/ijel.v7n2p99

Aida, Y. (1994). Examination of Horwitz, Horwitz, and Cope's construct of foreign language anxiety: The case of students of Japanese. Modern Language Journal, 78, 155. https://doi.org/10.1111/j.1540-4781.1994.tb02026.x

Altaf, S., \& Soomro, Niaz. (2014). Foreign language anxiety and willingness to Communicate in English. ELF Annual Research Journal, 16, 23-44

Braun V. \& Clarke V., (2006).Using thematic analysis in psychology. Qualitative Research in Psychology, 3, 77-101. https://doi.org/10.1191/1478088706qp063oa

Creswell, J. W. (2003). Research design: qualitative, quantitative, and mixed approaches (2ndEd.). California: Sage Publications. 


\section{Macrothink}

Education and Linguistics Research

ISSN 2377-1356 2020, Vol. 6, No. 2

Creswell, J. W., \& Plano Clark, V. L. (2011). Designing and conducting mixed methods research (2nd Ed.). Thousand Oaks, CA: Sage Publications, Inc.

Crystal, D. (1997). English as a Global Language .Cambridge: Cambridge University Press.

Dornyei, Z. (2003). Questionnaire in second language research: Construction, Administration, and processing. New Jersey: Lawrence Erlbaum Associates.

Dornyei, Z. (2007). Research methods in Applied Linguistics: Quantitative, qualitative and mixed methodologies, Oxford University Press.

Duff, P. (2008).Case study research in applied linguistics. New York, Taylor \& Francis Group, LLC.

Ellis, R. (1994). The study of second language acquisition. Oxford University Press.

Horwitz, E. K., Horwitz, M. B., \& Cope, J. A. (1986).Foreign language classroom anxiety. The Modern Language Journal, 70(02), 125-132. https://doi.org/10.1111/j.1540-4781.1986. tb05256.x

MacIntyre, P. D., \& Gardner, R. C. (1991a). Language anxiety: Its relationship to other Anxieties and to processing in native and second languages. Language Learning, 41, 85-117. https://doi.org/10.1111/j.1467-1770.1991.tb00691.x

Nazir, M., Bashir, S., \& Raja, Z. B. (2014). A study of second language speaking-anxiety among ESL intermediate Pakistan learners. International Journal of English and Education, 3(03), 216-229.

Tanveer, M. (2007). Investigation of factors that cause language anxiety for ESL/EFL learners in learning speaking skills and the influence it casts on communication in the target language. University of Glasgow. Masters Dissertation.

\section{Copyright Disclaimer}

Copyright reserved by the author(s).

This article is an open-access article distributed under the terms and conditions of the Creative Commons Attribution license (http://creativecommons.org/licenses/by/4.0/). 